\title{
Tomasz Scholl \\ Warsaw \\ EARLY GREEK FORTIFICATIONS IN THE TERRITORY OF THE LATER BOSPORAN CITIES
}

\begin{abstract}
Scholars have long debated the question how a small state like the Bosporus managed to remain independent for almost a millennium by the side of two nomadic giants, the Scythians and the Sarmathians. One of the reasons of their success were the fortifications that they had started building around their cities in the early stages of the colonization effort. Summing up the current knowledge of early Greek fortifications in the territory of the future Bosporan state, one cannot but note the weakness of the evidence. Changes of ground topography, natural and anthropic, have destroyed most of the earliest occupation sites. Practically none of the early Greek cities that should have had fortifications judging by their later histories are known.
\end{abstract}

Keywords: Early Greek fortifications; Bosporus

Scholars have long debated the question how a small state like the Bosporus (Pl. 1: 1, 2) managed to remain independent for almost a millennium by the side of two nomadic giants, the Scythians and the Sarmathians. It competed effectively with the great superpowers of the ancient world: Persia, Egypt, Macedonia and Rome and one of the reasons of their success were the fortifications that they had started building around their cities in the early stages of the colonization effort. The answer is not straightforward. Cities like Gorgippia (Alekseeva 2003) were fortified most probably in the first settlement phase (the end of 6th century BC), possibly because they bordered on territories occupied by the warlike Caucasian highlanders, a situation that made defenses a necessity. The small Bosporan 
cities of Akra (Kulikov 2003), Porthmion (Vahtina 2009a), Torikos (Onajko 1980) and the later Tanais (Arsenyeva 2007) had fortifications that were erected most probably simultaneously with the houses of the first colonists (in the 6th century BC) because their role was either to protect access to the densely populated lands first colonized in the Cimmerian Bosporus (Akra, Porthmion) or to protect the residents and merchants from the mountain tribes (Torikos), or because they had to fend for themselves owing to the sizable distance from other Bosporan towns (Tanais).

The Greeks arrived in the northern Black Sea littoral at the beginning of the Nymphaion transgression (in the second half of the 7th century BC), when the sea level was lower than today, determined at between $5 \mathrm{~m}$ and $12 \mathrm{~m}$ depending on the researcher (Golenko 2007, 189, with the newest references). Over time the water level rose, gradually flooding the lower-lying ground. In some places the material evidence for the presence of the first colonists is difficult to trace because the settlements were situated often by the seaside. A few important cities, especially on the Taman peninsula, have never been found and it is perhaps for this reason that nothing is known of the Greek presence on the northern coast of the Azov Sea. The higher-lying settlements continue to be destroyed by abrasion, e.g. the progressing destruction of Kytaion (Molev 2010) as well as Nymphaion (Sokolova 2007) and its chora (Scholl and Zin'ko 1999). Seismic activity was strong in the region between the 4th century $\mathrm{BC}$ and the 3rd century AD. Written sources recorded some of the catastrophes, like the one of 63 BC (Dio. Cass. 37.11). Landslides have also made research on early settlement difficult; this is illustrated particularly well by the slopes of Opuk hill where Kimmerikon once stood (Golenko 2007). Regular quarrying of stone building material from the ruins, by local inhabitants as well as by the civil and military authorities in particular, should also be mentioned. Wars, starting from the Crimean War through the Civil War to World War II, caused substantial damage to the archaeological sites and finds, as well as scientific documentation. Irreparable losses were done in the early 1990s by illicit diggers working with very modern equipment on an unprecedented scale. Earlier plundering concerned mostly the cemeteries.

Archival, mainly 19th century, materials are the source of further problems. Some of the documentation has been lost and other records have survived solely as descriptions, without any plans or finds. On most maps, plans and drawings, the urban layouts reflect the last stages of their existence, that is, a situation from the first centuries AD. The plans show 
the cities before they became quarries for salvaged stone building material, but it is still difficult on these grounds to reconstruct the earlier periods in the existence of these. Hence the limited use of these sources recently made available in a book by I. Tunkina (2002).

Thus, the beginnings of Greek settlement in the Bosporus are lost in the darkness with insufficient written sources and very modest archaeological sources. It is not clear when the first settlers came to these territories. It may have taken place in the first three decades of the 6th century (Zin'ko 2014, 292-293), and it is possible that Greeks were present in the area as traders. It is to be kept in mind that in antiquity the border between Europe and Asia (P1. 1: 2) passed through the current Kerch Strait (ancient Kimmerian Bosporus), the Azov Sea (ancient Maiotis) and the river Don (ancient Tanais). The shores of the Kimmerian Bosporus was where the first Greek settlers made a home for themselves. Another spot was the mouth of the Tanais where it flowed into the Maiotis, that is, the city of Kremnoi, of which little is known (Kopylov 2002).

The first settlers were challenged more by the forces of nature than by the local tribes. The sources intimate nothing about military action on the part of the tribes against the settlers. The first evidence of burning in Myrmekion dates from the mid-6th century BC, but is not accompanied by any evidence of raiding (Vinogradov 1999, 290). Fires were fairly common in ancient settlements, due to either living conditions or natural forces. Ravages caused by military action are known from the cities from layers of the end of the 6 th and early 5 th centuries BC. An exception in this respect are the earlier damages to the Archaic fortifications of Torikos.

The location, whether on one or the other side of the Kimmerian Bosporus, determined the kind of building material that prevailed: stone on the European side, mud brick on the Asian side. The Kerch peninsula and the vicinity of Tanais were rich in beds of limestone, while building stone was largely missing from the Taman area, Gorgippia being an exception as it was built on a limestone hill that served as a quarry. The debate on whether the upper parts of walls were of stone or mud brick is theoretical; it is reasonable to suppose that wherever stone was more easily available locally (outcrops of limestone and sandstone can be seen in places), it would have been used more often than mud brick.

The author has recently discussed urban fortifications built before the middle of the 1st century BC (Scholl 2014), while the embankments were described by him in an article published in 1981 (Scholl 1981). Since 
then a substantial amount of fieldwork has been carried out to verify ideas related to the existence and form of these defenses (Maslennikov 1998; Maslennikov 2003; Gavrilov 2004; Ermolin 2010).

The embankments, both existing and hypothetical ones, were referred to traditionally by different names; hence a numbering system has been proposed in order to avoid any misunderstanding in the scholarly debate. The first embankment was near Pantikapaion, embankment II ran from Lake Uzunlar to the Azov Sea, embankment III encircled Nymphaion, embankment IV was near Kytaion, V near Theodosia, VI cut across Perekop cape, VII protected cape Fontan from the east (Scholl 1981, 344-345). Not all of these defenses need to have been contemporaneous. For example, embankment VI seems to be a later addition, namely, it appears to have been constructed when the island that existed here during the times of the original Greek colonization was joined to the mainland. A RussianGerman expedition (Schlotzhauer and Zhuravlev 2014, 213) working currently on the site has undertaken geoarchaeological investigations to resolve the issue. Embankment II also seems to be later than the period in question, being connected with the Archeanaktid dynasty at the earliest or the first Spartokids. The same may be true of embankment V, as the need to fortify the western flank of the Bosporan state coincided with the incorporation of Theodosia into the Spartokid domain; for many centuries this border remained unchanged.

Thus it may be assumed that only the European part was defended by a system of earth embankments preceded by a system of ditches on the western side. Considering Herodotus' (4.12) information about the Kimmerians retreating from the Scythians behind successive embankments, it would mean that they first made embankment II, followed by I, III and IV; it may be assumed then that in extending their territories the Greeks first renovated embankments I, III and IV, and then embankment II (Scholl 1981, 348). There is no certain archaeological evidence, however, for the use of embankments as fortifications in the early phase of Greek colonization in the region.

Additional elements, like towers and garrisons, presumably did not appear on the embankments before the high period in Bosporus development, that is, in the second half of the 4th century BC. The early Greek settlers chose naturally defensive locations on the sea with fertile lands extending around them. These original places became acropoleis over time (Myrmekion, Pantikapaion). Pantikapaion developed into the biggest city on the Bosporus and the state capital (Pl. 2: 1). 
The defensive system of Pantikapaion, its acropolis in particular, was reconstructed tentatively by Tolstikov (1984, 28ff.; 2010b). Defense wall 115, fragmentarily exposed in 1949 in the Esplanadnyj trench (Blavatskij 1957, 7), must have belonged to an early period, possibly even the 6th century BC. The foundation, now surviving to a maximum height of $1.21 \mathrm{~m}$ and width of $2.34 \mathrm{~m}$, was composed of huge dressed stones. It may be part of a fortification predating the arrival of the Greeks, possibly a Cimmerian fortified shelter, according to Blavatskij. The wall was dismantled almost entirely not later than the first half of the 5th century BC (Blavatskij 1957, 25) or even its beginning (Blavatskij 1964, 14). It may have also been the fortified settlement of the first colonists when they first arrived. Tolstikov (2001a, 48), however, does not believe in its defensive function.

Tolstikov and others (Tolstikov et al. 2003, 319ff.) were of the opinion that earlier fortifications existed on the acropolis before the construction of the palace of the Spartokids. The acropolis, which was the best fortified part of the Greek city, was built in the second phase of building period II, at the end of the 6 th century BC. The earliest known fortifications, defending the entire region of the First Throne, date to this period.

Tracing the boundaries of the acropolis, which centered on the peak of the First Throne, was a major research task that Tolstikov (2000, 303ff.) took upon himself. The ground topography on the east and south formed the natural boundaries, according to the scholar. A rock ledge to the west of the First Throne is the highest peak at $92 \mathrm{~m}$ a.s.l. and the central point of the acropolis; its cut-back cliff descends onto the fairly flat and even western plateau of the Hill of Mithridates. Natural steep slopes form the eastern and southern edges of this plateau. Rock outcrops can be seen with evidence of rock-cutting under the fortifications.

Building appears to have been hurried in the early phases, taking advantage of the topography and using stone from earlier ruined structures. Layers of destruction of this earlier architecture have yielded, among others, numerous Scythian arrowheads from the second half of the 6th and early 5 th century BC.

The town of Myrmekion may have also acted as a central distribution center for the colonists in the early stages of the colonization (P1.2:2). The first defenses were constructed in the middle (Vinogradov 1999, 290) or the third quarter of the 6th century BC (Butâgin 2006, 19). A wall was built on a rock ledge in the southwestern part of the town, cutting off access to the highest part of the hill. The stone socle of this wall, which was presumably of mud brick, has survived in place. This base (walls 37 and 58) was approximately 
a meter wide and followed the ground relief, incorporating natural rock outcrops (Pl. 3). Wall 37 adjoined steep rock cliffs at both ends, on the east and west, protecting the ascent to the acropolis from the side of the gentle slope. It stands on pits dating from the second quarter of the 6th century BC. Wall 58, standing on a rock (with a smaller tower-like projection next to it), consisted of two separate walls, one earlier and the other later, fortifying the original complex. The reinforcement may have been added in the end of the 6 th or the early years of the 5 th century BC. The cultural layer underlying the wall foundation yielded Chian amphorae sherds typical of the second half of the 6th century BC, as well as a fragment of an Attic kylix and the neck of an Ionian jug from the same period. The wall turned at right angle a number of times, forming two tower-like projections, one $4 \mathrm{~m}$ long and the other just $1.2 \mathrm{~m}$ long. The stones of the wall foundation were large and undressed, laid straight on the rock ground in places, the gaps between them filled with smaller stones bonded in clay. The building technique resembles closely the early fortifications of Porthmion; thus, they are one of the earliest examples of fortifications in the northern Black Sea littoral. The original fortified acropolis was no bigger than $150-200 \mathrm{~m}^{2}$, although Vinogradov $(1995,35)$ estimated the area to be closer to $320 \mathrm{~m}^{2}$. The acropolis may have lost its military function within its old borders possibly already in the beginning of the 5th century BC (Butâgin 2006, 20).

Porthmion was a highly peculiar city in that it was surrounded by masonry walls on all sides from the start. Vestiges of the earliest fortifications were uncovered in 1986 in the eastern and southeastern parts of the city (P1. 4). The eastern wall, traced on a length of $12.8 \mathrm{~m}$, ran parallel to the natural plateau edge. It was heavily reinforced in view of the easy approach to the site afforded by the gentle slope here. The stone foundation rested on huge blocks of limestone reaching $1.2 \mathrm{~m}$ in length and $0.6 \mathrm{~m}$ in width (Vahtina 1995). The stone blocks higher up in the wall were of smaller size and the interstices between them were filled with stone debris and earth. The wall was roughly $1-1.1 \mathrm{~m}$ wide and survives to a height of $1.2 \mathrm{~m}$. The upper section may have been made of mud brick in all probability.

The southern part of the Archaic defenses was based on a natural rock outcrop, running in a broken line and forming a natural kind of a tower. Parts of it have been preserved over a distance of $20 \mathrm{~m}$. The rock cliff was undercut in places to accommodate the fortification, while gaps in it were filled with stones, rubble and earth. Like the east section, the southern one ran along the edge of the plateau, over a very steep gully slope. There may have been a tower in its southwestern part (Vahtina 2008, 53). 
A section of the early defenses was observed also in the southwestern part of the city, while excavating some later residential architecture. It formed the side wall of one of the houses. The rest appears to have been dismantled when the new building project was executed.

A rainfall disposal channel had been constructed against the inside face of the east wall. A section $10 \mathrm{~m}$ long was reserved. It was $0.4 \mathrm{~m}$ deep and 0.35-0.4m wide (Vahtina 2009b, 69). At the southern end it opened outside the defenses. In the next building phase, the channel was built up and huge blocks of limestone sealed its mouth.

The walls were erected in the second half of the 6th century BC and are considered the oldest Greek fortifications in the northern Black Sea littoral. The dating is based on the oldest pottery material from the lowest layers next to the wall foundations, compared with the pottery assemblage from the water channel. This included primarily sherds of amphorae from Miletus and Klazomenai, as well as table ware. The only defenses that were contemporary with the early wall of Porthmion are the defenses on the Myrmekion acropolis (Vahtina 2009a, 94). They suffered from a severe conflagration in the end of the 6th century, but were rapidly rebuilt and existed in unaltered form and course throughout the Classical period.

Tyritake played an extremely important role, blocking a potential attack on Pantikapaion and Myrmekion from the south. In the end of the 6th and the beginning of the 5 th century $\mathrm{BC}$ nomads threatened to raid the Bosporus. Defenses started to be built, some better, some worse. Nothing is known of the Tyritake fortifications from before this time, although earth embankments cannot be excluded and those would be difficult to trace. In the early 5th century BC (first half of the age, Gajdukevič 1971, 57), Tyritake was defended by a stone wall which incorporated also the outer walls of earlier structures. On the one hand, it attests to a hurried construction, but it may also indicate a downplaying of the threat by the Greeks. Money was also an issue. Some of the buildings were destroyed during the construction or their walls served as substructures for the fortifications. The walls presumably surrounded all 5ha of the town (Zin'ko 2014, 306308). A section of double-faced wall, 1.7-1.8m wide, was uncovered in trench I (Marti 1941, 14). It was built of large well-dressed limestone slabs lining a core of smaller stones and pebbles bonded in clay. Pottery of the 6th century $\mathrm{BC}$ was found in culturally sterile layers at the base of the foundations. Two other sections of these fortifications, approximately $2 \mathrm{~m}$ wide, were found on the western side, in trenches V-VI. This wall (no. 106) was erected of large undressed limestone chunks which were not bonded (Knipovič 
and Slavin 1941, 42). Found in the lowest course of this wall were two anthropomorphic stelae from the 3rd millennium BC (Zinko 2003, 829).

The defense wall in trench XIV (curtain walls 2 and 2a) joined two buildings from the mid 6th century $\mathrm{BC}(\mathrm{Pl} .5)$, that is, the outer walls 18 and 72 of these buildings (Gajdukevič 1952, 87). The damage to these walls is substantial, but their course and manner of construction are still evident. Walls $2 \mathrm{a}$ and 71 are interbonded in the lower part, 2a starting to overlap 71 from the fifth course up. At this point the width of the wall was $1.71 \mathrm{~m}$. Further north, inside an Archaic structure, one can see some stones, which could be part of the defense wall running across the structure. The building was probably already out of use when the defense wall was built. Inside the building, a paved surface (no. 80 ), $0.68 \mathrm{~m}$ wide, appeared alongside curtain 2a. This particular wall, of which some $13 \mathrm{~m}$ were cleared, was built of broken stone bonded in clay, the stones in the facing being larger and roughly squared. Its northeastern end was joined to wall 75 , a small fragment of which was cleared inside the trench. It may have been part of a tower, but the ancient remains in this part of the town were annihilated during World War II (Gajdukevič 1952, 87).

The uncovered section of wall 2 stretched $15.25 \mathrm{~m}$ in a southeastern direction from wall 23, which was part of the oldest Archaic building. The southern termination of wall 2 had been dismantled completely, whereas the northern end joined the building. At this point, the wall was up to $2 \mathrm{~m}$ wide, tapering to $1.7 \mathrm{~m}$ at the other end. The inner face of wall 2 at the joining with wall 23 was reinforced by adding an additional face of large limestone slabs. These slabs overlap wall 23, hence wall 2 should be considered later in date, especially as it is founded on a slightly higher level than wall 23.

It seems obvious that walls 2 and 2 a were constructed at the same time and in response to a situation of external danger. Numerous finds of bronze arrowheads outside of wall $2 \mathrm{a}$ can be considered as proof. The steepness of the slopes, on which the defenses were constructed should also be emphasized.

Phanagoria was the biggest city and later capital of the Asiatic part of the Bosporus state. During the Archaic age it may have given way in precedence to Kepoi and Hermonassa. Heavily damaged sections of the lower parts of a fortification (wall 72) were discovered in the southeastern part of the city (Kobylina 1969, 98-99). Huge flattish chunks of sandstone interspersed with debris and single stones formed the lowest course of this wall, which was erected on a substructure of sand up to $0.7 \mathrm{~m}$ deep in places and leveling the ground surface under fortifications $4 \mathrm{~m}$ thick. The upper 
courses of this wall would have been built of mud brick. After Zavojkin (2004, 51-52) this wall was built in the second part of 5th century BC.

The most important town of southern Bosporus was Gorgippia, but there is very little information about its Archaic-period fortifications. Sections are invisible under modern building, while other parts were used to construct new lines of defenses. The earliest recorded remains, found in the 'Okean' trench (P1. 6: 1), comprised a presumed ditch about $2 \mathrm{~m}$ deep, $2.2 \mathrm{~m}$ wide at the bottom and spreading to $4.5 \mathrm{~m}$ at ground level (Alekseeva 1997, 14). A 60m long section (Pl. 6: 2) of this ditch was investigated, which appeared to encircle the area from the west. The inside slope of the ditch may have been topped by wattle-and-daub defenses. The fortifications protected semisunken huts, possibly also more solid, public structures but the patchy character of the excavations carried out in this area do not permit any more definite conclusions. The ditch appears to have been filled in already in the second building stage, when a house (no. 1) with walls one meter thick was constructed on the spot. The fill of the ditch yielded amphora sherds, including Chian vessels with bulging necks, proto-Thasian amphoras and containers from Clazomenai, the latter decorated with broad red lines. The material is dated from the end of the 6th to the early 5th century BC (Alekseeva 2003, 19). House 1 could have easily been a defensible building itself.

Another city playing a significant role in the colonization process was Patrasis (Pl. 7). The upper town was fortified from the second half of the 6 th century BC (Abramov and Zavoykin 2003, 1124). One of the defensive features was a ditch, $4 \mathrm{~m}$ wide and at least $1.56 \mathrm{~m}$ deep, separating the upper town from the eastern and western economic zones (Abramov 2010a, 11), at the same time the ditch cut the peninsula off from the steppe (Abramov $2005,34)$. Stratigraphic exploration of the fill confirmed its natural origins (Abramov 2000, 7).

Torikos was the most important center of Greek settlement in the foothills of the Caucasus (Onajko 1980). The fortifications used local marl stone, taking advantage of ground relief, especially the rock outcrops as a base for the defense walls (Pl. 8). Larger stones, mainly slabs, were laid in the foundations and were also occasionally used in the upper wall courses. Larger stones were also used in the wall faces, while the core consisted of smaller rocks, all bonded in a loose clay mortar. Only one entrance to the fort has been recorded; it was situated near the western corner, on the southwestern side. Wall 1 , which measured $0.8 \mathrm{~m}$ in width, protected the fort from the east; it was constructed of large, long, neatly laid blocks 
forming two faces for a core of smaller stones bonded in clay. The lower courses were more likely to be formed of large blocks. Level with unit W, the walls were given an additional facing about $0.4 \mathrm{~m}$ wide, forming a kind of a tower, which measured $1.2 \mathrm{~m}$ wide, extending for $4 \mathrm{~m}$. The wall and the additional facing were contemporaneous. The full length of the wall running north to unit $\mathrm{B}$ is not known, the wall having been damaged by a modern pit beyond which there is the cliff. Transverse inner walls joined wall 1.

Unit I, which covers more than $24 \mathrm{~m}^{2}$, projected $4.5 \mathrm{~m}$ from the southern curtain, just $30 \mathrm{~m}$ east of the gate entrance. It must have been the room inside a tower guarding the gate. The tower has three outer walls: the southern one (no. 17), the eastern one (no. 1) and the western one (no. 16). Wall 29 is shared with unit E. Wall 1 is interbonded with wall 17, which is $0.8 \mathrm{~m}$ wide and is built of large stones, especially in the lower part. Wall 17, the known length of which is $7 \mathrm{~m}$, was built of stones that were smaller than those in wall 1, although it also has large stones in the lower courses. Interbonded with wall 17 was wall 16 , which was $6.3 \mathrm{~m}$ long and $0.7-0.75 \mathrm{~m}$ wide. Remains of a floor pavement inside the tower room (no. 27) survived chiefly in the northeastern part and in the entrance to unit E; it comprised flat stones of irregular shape bedded in natural clay and bonded with a clay mortar. Two stone supports were found standing in unit I, both rectangular, one (no. 25) built of stones in a clay mortar, $0.55 \mathrm{~m}$ high and attached to wall 1 , the other (no. 28), measuring $1.65 \mathrm{~m}$ by $1 \mathrm{~m}$, attached to wall 17 . The excavator believes these supports to be platforms either for stone steps (Onajko 1980, 23 ) or wooden ladders operating inside the tower.

The defense wall (no. 5) on the south was $30 \mathrm{~m}$ long and $0.5-0.7 \mathrm{~m}$ wide; it was not as well preserved as wall 1, being dismantled almost completely in places, but even so, the bondwork seems to have been more regular than in wall 1 . Transverse inner walls were interbonded with wall 5 . On the other side of the gateway, wall 5 was continued by wall 62, only fragmentarily preserved (3.6m surviving length, $0.8 \mathrm{~m}$ wide); the faces of this wall, especially on the outside, were constructed of large and well fitted stone slabs.

Unit $\mathrm{T}$, which was a passage leading from the main gateway inside the complex, can be found between units $\mathrm{S}$ and U. It was $8 \mathrm{~m}$ long and $2.2 \mathrm{~m}$ wide. That was the width of the entrance at the southern end, fitted with a threshold (no. 63) made up of five large slabs, the largest one being $0.75 \mathrm{~m}$ by $0.6 \mathrm{~m}$ and $0.08 \mathrm{~m}$ thick. The west wall (no. 68) featured large blocks 
of stone in the lower courses on the passage side. A paved area at the northern end (no. 106) suggests that the entire unit was paved. The west wall (no. 61), which was $9 \mathrm{~m}$ long and is missing the middle part, removed down to the foundation, also ended at the southern end of this paved area. At the southern end this wall was up to $0.7 \mathrm{~m}$ wide, narrowing to $0.5 \mathrm{~m}$ at the northern end, away from the entrance. It was built entirely of middlesized stones.

As for the western defense circuit, all that has remained is the rubble (no. 104) and a fragment of a wall (no. 105) closing unit H. This wall, $0.6 \mathrm{~m}$ wide, was built of large slabs up to $1 \mathrm{~m}$ long and $0.2 \mathrm{~m}$ thick; the slabs were the largest especially in the outer face of the wall.

After the first destruction, in which the western fortifications of Torikos suffered the most, a reinforced wall 68 took over as the town defenses along with the newly built wall 90, which linked the new unit SZ with unit $\mathrm{H}$. The old entrance was blocked using, just like for the new walls, stone salvaged from the destroyed part of the town. Wall 90 was $0.8 \mathrm{~m}$ wide and had an outer facing of well fitted regular slabs, the largest of which were used for the lowest course. Later a parallel wall (no. 59), which was $0.5 \mathrm{~m}$ wide, was added on to it on the inside. At the northwestern corner of unit $\mathrm{SZ}$, wall 90 turned to the southeastern corner of unit $\mathrm{H}$, running for $5 \mathrm{~m}$; in the next building phase, it was reinforced on the outside with wall 91 that reached one meter in width.

Unit $\mathrm{F}$ was added on the southern side of units $\mathrm{R}$ and $\mathrm{S}$; it was rectangular, the inside measurements being $10.5 \mathrm{~m}$ by $1.4-2 \mathrm{~m}$. It served most probably as a tower or rampart. Wall 5 was dismantled completely along the width of both units. It is impossible to tell whether this happened during renovation work in antiquity (and unit $\mathrm{F}$ would simply constitute the remains of units $\mathrm{R}$ and $\mathrm{S}$ ) or whether the stone was salvaged in modern times and an entirely new room was built in this spot in antiquity. Perhaps the entrance to the town had led through this new unit $F$ once unit $U$ and the entrance had been destroyed. Undoubtedly, the fact that this room projected from the southern face of the defenses gave it a defensive function as well. Walls 60 and 70 constituted the outside perimeter of this unit from the south, wall 79 from the east and there is no west wall as the new gateway to the town may well have been situated here (Onajko 1980, 48). Wall 58 was founded on a sand bedding that was at least $0.3 \mathrm{~m}$ deep. It was $1 \mathrm{~m}$ wide with an inner facing of large, well fitted stones, including a $1.8 \mathrm{~m}$ long slab. Wall 70 was up to $0.7 \mathrm{~m}$ wide and was interbonded with the east wall (no. 79), which was 
also $0.7 \mathrm{~m}$ thick and running for $3 \mathrm{~m}$. All the walls of unit $\mathrm{F}$ were constructed of well fitted stones, especially the outer faces in which large slabs were used particularly in the lower courses.

A different and more likely theory contrary to Onajko's positioning of the new entrance holds that the passage led through unit $\mathrm{O}$, thus giving reason for the reinforcing of wall 5 on the inside and outside (east and west sides respectively). Two towers would have additionally protected an entrance in this place from the east and west. However, a modern robber's pit in this spot makes it impossible to verify this idea with any certainty.

The outer lines of defenses were reinforced primarily in the third building phase. Additional internal walls appeared in units I and SZ, and parallel walls were added to existing ones in other places: wall 5 (in units $\mathrm{L}, \mathrm{N}, \mathrm{O}$ and $\mathrm{P}$ ), wall 59 (in units $\mathrm{S}$ and SZ), wall 93 in unit $\mathrm{H}$. Unit $\mathrm{F}$ also received a new set of walls: nos. 75,80 and 81 . The building material in these new walls often included sea pebbles and local boulders, bonded in a clay mortar. The workmanship is generally poorer than in the case of the older walls.

Unit I was also rebuilt on the inside with wall 13 being added to wall 29 , making it $1.3 \mathrm{~m}$ thick overall (twice the original width). The added wall stood on an occupational layer up to $0.8 \mathrm{~m}$ thick. Wall 16 was given added height and perhaps also width, becoming interbonded with wall 13 in the upper parts. The doorway was also blocked at this time. A wall (no. 15) was built inside the room, projecting west from wall 1 . Destruction in this part of the unit leaves unanswered the question of whether the wall reached wall 16 or whether there was an intentional narrow passage left in it by wall 16. In any case, two separate units were formed in this fashion, the northern one $\dot{Z}$ and the southern one $\mathrm{Z}$. Wall 15, 0.8m wide and surviving for a length of $4.45 \mathrm{~m}$, stood on a gravelly layer up to $0.45 \mathrm{~m}$ deep plus up to $0.6 \mathrm{~m}$ loess, thus placing its footing more than a meter above the foundation level for the older structures.

Wall 5 was reinforced with additional walls. Wall 38 was constructed inside units $\mathrm{L}, \mathrm{N}$ and $\mathrm{O}$; it was $0.6-0.8 \mathrm{~m}$ wide. On the outside of unit $\mathrm{P}$, wall 54 was hastily put together. This made the wall twice as thick as before, the width being now $1.3 \mathrm{~m}$, while reducing the size of the rooms at the same time. The additional walls were founded on a level $0.7 \mathrm{~m}$ higher on the average than the original wall 5.

Room $\mathrm{F}$ was given an additional wall (no. 75), reinforcing the old walls 70 and 79. It ran in a slightly arching line. A poorly preserved wall (no. 81) was constructed perpendicular to its orientation. The bedding layer for all the new walls contained few artifacts next to a large amount of charcoal 
from burned structures. Wall 81 presumably divided unit F into two. Only a small fragment of wall 64 was preserved, it being a defensive wall and a continuation of wall 60 . These two walls fortified the southwestern corner of the fort, thus making unit $\mathrm{F}$ another tower, similar to unit I. The main gate could have been located in this period between walls 60 and 70 .

The west walls of units S and SZ were reinforced with an additional wall (no. 59), built on an occupational layer up to $0.6 \mathrm{~m}$ thick, thickly mixed with charcoal. In its western part this wall was $0.35 \mathrm{~m}$ thick, in its northern part $0.5 \mathrm{~m}$ thick, thus extending the overall width of the defenses in this place to $1 \mathrm{~m}$.

Wall 91 was added on the outside to wall 90, which joined units SZ and $H$. The overall length of wall 91 was $6.4 \mathrm{~m}$, its thickness $0.65 \mathrm{~m}$, raising the overall thickness of the defenses here to $1.6 \mathrm{~m}$. It was constructed of large and middle-sized slabs, standing on an occupational $0.4 \mathrm{~m}$ thick layer.

Wall 93 was also added in unit $\mathrm{H}$, forming together with the older wall 92 a single line $1.6 \mathrm{~m}$ thick. It, too, stood on an occupational layer up to $0.45 \mathrm{~m}$ thick. The west wall (no. 105) was reinforced on the inside with wall 102 , the joined walls giving the same thickness as recorded in the case of the south wall (nos. 92 and 93).

Summing up the current knowledge of early Greek fortifications in the territory of the future Bosporan state, one cannot but note the weakness of the evidence. Changes of ground topography, natural and anthropic, have destroyed most of the earliest occupation sites. Practically none of the early Greek cities that should have had fortifications judging by their later histories, is known. On the European side there is Akra (a defensive ditch and embankment may have been used in the earliest occupational phase), Kimmerikon (possibly the first settlers occupied the upper plateau with very steep cliffs rising $40 \mathrm{~m}$ high) and Theodosia. Nothing is known about the early fortifications of the Asiatic cities of Hermonassa, Kepoi, Labrys.

The Greeks settling the European side of the Bosporus probably met with no resistance from the local tribes. The Kerch peninsula in this period was probably poorly populated in this period giving the Greeks time to prepare for contacts with the Scythians. The situation in Taman peninsula is not clear. The region should have been settled by Meotians, especially Scythians, who were quite advanced in terms of civilizational development. Hence presumably the active participation of these tribes in trade on one hand and on the other, their organized resistance to the Greeks as attested by the war led by Queen Tirgatao (Polyaenus 8.55). The Greeks not only had to defend their cities, but they were also forced to protect their agricultural 
hinterland. Stone fortifications could be built around the cities, but fields could be protected solely by defensive ditches and embankments. Such a system, comprising a ditch and embankment, was widely used by the first Greek settlers (Gorgippia), as well as by the local tribes, the Meotians and Scythians. The early settlements presumably had to satisfy certain conditions: seaside location, best on a peninsula, convenient harbor, cultivable land nearby. A cape extending into the sea had to have a river or other source of potable water near it. The cities were fortified first and only after that were efforts made to protect the agricultural land, which is connected in turn with new permanent settlements in the chora. Neither should one exclude fear of annexation by neighbors as a reason for fortifying settlements near other Greek settlement centers.

The different situation of towns on the Asiatic side of the Bosporus, compared to those on the European side, in terms of external threat in the early stages of the colonization, is well illustrated by the fortifications of Torikos, a city of Greek settlers lying in a hostile environment and far from other settlements of their compatriots. The sound and repeatedly reinforced defenses were aimed at defending the population. The layout suggest a refugial function. The large inner courtyard presumably surrounded by walls (three sides have been preserved) and clusters of rooms inside these fortifications provided enough space to shelter not only the ship crews with their goods, but also the farmers from around the town with their livestock.

Thus, we know that the first Greek settlers fortified their cities and that the strength of these fortifications depended on the threat: defenses were much stronger on the Asiatic side of the Kimmerian Bosporus. However, there seem to have been other factors than just external threat as well. The acropolis of Myrmekion was fortified already in the second half of the 6th century BC, and Porthmion was given fortifications as well. While the residents of Myrmekion could have easily dealt with the fortifications around the small acropolis of their town, it is not clear who constructed the strong forts of Porthmion, as well as Torikos. The inhabitants of these two towns had neither the manpower nor the resources to complete building projects on such a grand scale. Thus, it seems evident that at least some of the Greek cities took advantage of aid from outside, possibly from their mother cities.

Independently of the quality of the defensive architecture and funding sources, Greek settlement in the territory of the future Bosporan state succumbed to a common catastrophe that came from outside. Evidence of destruction is evident in Kepoi in the third quarter of the 6th century BC 
layers. Phanagoria was destroyed in the end of the 6th century BC, at the same time that Porthmion, too, was razed. The destruction in Torikos and Nymphaion is dated to the same period. These events presumably prompted a political consolidation of the settlers. In the opinion of V. Tolstikov (2001b, 47), around $480 \mathrm{BC}$, the Greeks on both sides of the straits came together under the leadership of Pantikapaion and the dynasty of the Archeanaktids. But that is an entirely new phase of the history of the Bosporus.

\section{References}

Abramov A. P. 2000. Абрамов А. П. Западная граница Патрейского городища. Древности Боспора. Международный ежегодник по истории, археологии, эпиграфике, нумизматике и филологии Боспора Киммерийского 3, 7-10.

Abramov A. P. 2005. Абрамов А. П. Патрейское городище. Сведения античных авторов. In Патрей. Материалы исследования 2, 7-53. Moscow.

Abramov A. P. 2010a. Абрамов А. П. Динамика торговых связей Патрея во второй половине VI-V вв. до н.э. по материалам керамической тары. Древности Боспора. Международный ежегодник по истории, археологии, эпиграфике, нумизматике и филологии Боспора Киммерийского 14, 9-27.

Abramov A. P. 2010b. Абрамов А. П. Патрей. In Античное наследие Кубани, 529-539. Moscow.

Abramov A. P. and Zavoykin A. A. 2003. Patraeus-CimmerisAchilleion. In D. V. Grammenos and E. K. Petropoulos (eds.), vol. 2, 1103-1154.

Alekseeva Е. М. 1997. Алексеева Е. М. Античный город Горгиппия. Moscow.

Alekseeva E. М. 2003. Алексеева Е. М. Анапа. Динамика развития центральной части античного города (VI в. до н.э.-III в. н.э.). Древности Боспора. Международный ежегодник по истории, археологии, эпиграфике, нумизматике и филологии Боспора Киммерийского 6, 18-43. 
Arsenyeva T. M. 2007. Arsenyeva T. M. Tanais. In D. V. Grammenos and E. K. Petropoulos (eds.), vol. 2, 1047-1102.

Blavatskij V. D. 1957. Блаватский В. Д. Строительное дело Пантикапея по данным раскопок 1945-1949 и 1952-1953 гг. Материаль $u$ исследования по археологии СССР 56, 5-95.

Blavatskij V. D. 1964. Блаватский В. Д. Пантикапей. Очерки по истории столиць Боспора. Mоscow.

Butâgin A. М. 2006. Бутягин А. М. Акрополь Мирмекия в свете археологических исследований. Боспорские исследования 13, $16-30$.

Butâgin A. M. and Vinogradov Ü. A. 2006. Бутягин А. М., Виноградов Ю. А. Мирмекий в свете новых археологических исследований. St. Petersburg.

Ermolin A. L. 2010. Ермолин А. Л. О датировке земляных оборонительных сооружений Боспора. Древности Боспора Международный ежегодник по истории, археологии, эпиграфике, нумизматике и филологии Боспора Киммерийского 14, 130-161.

Gajdukevič V. F. 1952. Гайдукевич В. Ф. Раскопки Тиритаки в 19351940 гг. Материалы и исследования по археологии СССР 25, 15-134.

Gajdukevič V. F. 1971. Das Bosporanische Reich. Berlin.

Gavrilov A. V. 2004. Гаврилов А. В. Округа античной Феодосии. Simferopol.

Golenko V. К. 2007. Голенко В. К. Древний Киммерик и его округа. Simferopol.

Grammenos D. V. and Petropoulos E. K. (eds.) 2003. Ancient Greek Colonies in the Black Sea, vols. 1-2. (Publications of the Archaeological Institute of Northern Greece 4). Thessaloniki.

Knipovič T. N. and Slavin L. М. 1941. Книпович Т. Н., Славин Л. М. Раскопки юго-западной части Тиритаки. Материаль и исследования по археологии СССР 4, 37-60.

Kobylina М. M. 1969. Кобылина М. М. Сооружения V в. до н.э на южной окраине Фанагории. Краткие сообщения ИА АН СССР 116, 98-104.

Kulikov A. V. 2003. Akra and its Chora. In D. V. Grammenos and E. K. Petropoulos (eds.), vol. 2, 1023-1056.

Kopylov V. P. 2002. Копылов В. П. Греко-варварские взаимоотношения на Нижнем Дону в VII-VI вв. до н.э. Историкоархеологические исслледования в г. Азове и на Нижнем Дону в 2001 г 18/2002, 276-288. 
Marti Ü. Ü. 1941. Марти Ю. Ю. Городские крепостные стены Тиритаки и прилегающий комплекс рыбозасолочных ванн. Материаль $u$ исследования по археологии СССР 4, 11-24.

Maslennikov А. А. 1998. Масленников А. А. Эллинская хора на краю Ойкумень. Сельская территория европейского Боспора в аттичнуюэпоху. Moscow.

Maslennikov A. А. 2003. Масленников А. А. Древние земляные погранично-оборонительные сооружения Восточного Крыма. Moscow.

Molev E. А. 2010. Молев Е. А. Боспорский город Китей. (BI. Supplementum 6). Simferopol.

Onajko N. A. 1980. Онайко Н. А. Архаический Торик. Античный город на северо-востоке Понта. Моscow.

Paromov Â. М. 1993. Паромов Я. М. Археолого-топографический план Патрея. Боспорский сборник 3, 136-162.

Schlotzhauer U. and Zhuravlev D. 2014. Greek colonization in the Cimmerian Bosporus: Russian-German interdisciplinary investigations in southern Russia. In A. Twardecki (ed.), Tyritake. Antique Site at Cimmerian Bosporus. Proceedings of the International Conference, Warsaw, 27-28 November 2013, 203-219. Warsaw.

Scholl T. 1981. Fortyfikacje Państwa Bosforskiego od IV w. p.n.e. do poł. I w. p.n.e. Studia archeologiczne 1, 319-353.

Scholl T. 2014. Miasta bosporańskie od wieku VI po połowę I wieku p.n.e. Warsaw.

Scholl T. and Zin'ko V. 1999. Archaeological Map of Nymphaion (Crimea). Warsaw.

Sokolova O. Û. 2007. Nymphaeum. In D. V. Grammenos and E. K. Petropoulos (eds.), vol. 2, 759-802.

Šurgaâ I. G. 1984. Шургая И. Г. Порфмий. In Античные государства Северного Причерноморья, 69-70. Moscow.

Tolstikov V. P. 1984. Толстиков В. П. О системе обороны акрополя Пантикапея. Сообщения Государственного музея изобразительных искусств им. А.С. Пушкина 7, 28-56.

Tolstikov V. P. 2000. Толстиков В. П. Дворец Спартокидов на акрополе Пантикапея. (К проблеме локализации, интерпретации и графической реконструкции). Древности Боспора. Международный ежегодник по истории, археологии, эпиграфике, нумизматике и филологии Боспора Киммерийского 3, 302-339. 
Tolstikov V. P. 2001a. Толстиков В. П. Ранний Пантикапей в свете новых археологических исследований. Древности Боспора. Международный ежегодник по истории, археологии, эпиграфике, нумизматике и филологии Боспора Киммерийского 4, 385-426.

Tolstikov V. P. 2001b. Толстиков В. П. Археологические открытия на акрополе Пантикапея и проблема боспоро-скифских отношений в VI-V вв. до н.э. Боспорский феномен. Материаль международной конференции 1, 45-57.

Tolstikov V. P. 2010a. Толстиков В. П. Храм Аполлона на акрополе Пантикапея. Проблемы датировки, типологии и периодизации. Проблемы истории, филологии, культуры 1/27, 277-315.

Tolstikov V. P. 2010b. Толстиков В. П. План Поля Дюбрюкса и археология Пантикапея. In Dûbrûks P., Дюбрюкс П. Собрание сочинений. Составитель... И.В. Тункина, vol. 1, 463-470. St. Petersburg.

Tolstikov V. P. et al. 2003. Толстиков В. П., Журавлев Д. В., Ломтадзе Г. А. Многокамерные строительные комплексы в системе застройки акрополя Пантикапея VI-V вв. до н.э. Древности Боспора. Международный ежегодник по истории, археологии, эпиграфике, нумизматике и филологии Боспора Киммерийского 6, 307-350.

Tunkina I. V. 2002. Тункина И. В. Русская наука о классических древностях юуга России (XVIII-середина XIX в.). St. Petersburg.

Vahtina М. Ü. 1995. Вахтина М. Ю. О древнейших оборонительных сооружениях античного Порфмия. In Фортификация в древности и средневекове (материаль методолигического семинара ИИМК). Памяти И.Н. Хлопина, 31-33. St. Petersburg.

Vahtina М. Ü. 2008. Вахтина М. Ю. Порфмий - укрепленное поселение Греков у переправы через Киммерийский Боспор. Боспорские чтения 9, 51-59.

Vahtina М. Ü. 2009a. Вахтина М. Ю. Порфмий - греческий город у переправы через Киммерийский Боспор. Боспорские исследования 22, 91-126.

Vahtina М. Ü. 2009b. Вахтина М. Ю. Об элементах городского благоустройства Порфмия (по данным археологии). Боспорские чтения $10,68-75$.

Vinogradov Ü. А. 1995. Виноградов Ю. А. Укрепления акополя Мирмекия (предварительные итоги изучения). In Фортификащия в древности и средневекове (материаль методолигического семинара ИИМК). Памяти И.Н. Хлопина, 33-36. St. Petersburg. 
Vinogradov Y. A. 1999. Selected findings from the Myrmekion acropolis. ÉtTrav 18, 280-293.

Zavojkin A. A. 2004. Завойкин А. А. Фанагория во второй половине $V$ - начале IV вв. до н.э. (по материалам раскопок „Южного города”). (Древности Боспора. Международный ежегодник по истории, археологии, эпиграфике, нумизматике и филологии Боспора Киммерийского Supplementum 1). Moscow.

Zinko V. N. 2003. Tyritake. In D. V. Grammenos and E. K. Petropoulos (eds.), vol. 2, 827-854.

Zin'ko V. N. 2014. Зинько В. Н. Тиритака. Раскоп XXVI. Том II. Археологические комплексы VI-V вв. до н.э. При участи Буйских А. В. et al. (Боспорские исследования. Supplementum 11). Simferopol, Kerch.

Tomasz Scholl Instiute of Archaeology Warsaw University tomasz.scholl@gmail.com 

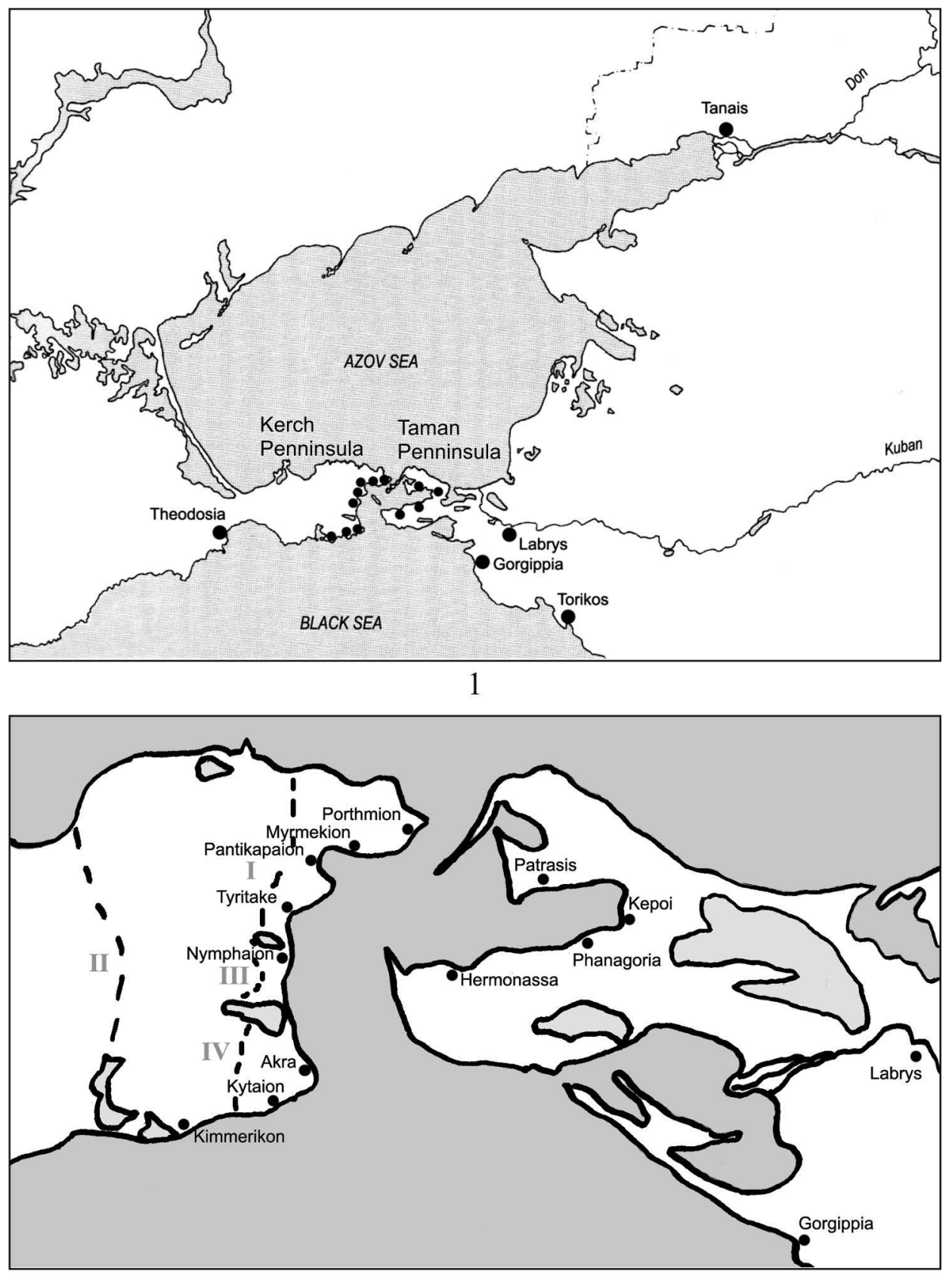

Pl. 1.1 - Kerch Strait with ancient cities. Drawing by J. Scholl; 2 - Ancient cities of Greek period of Bosporan Kingdom. Drawing by J. Scholl 

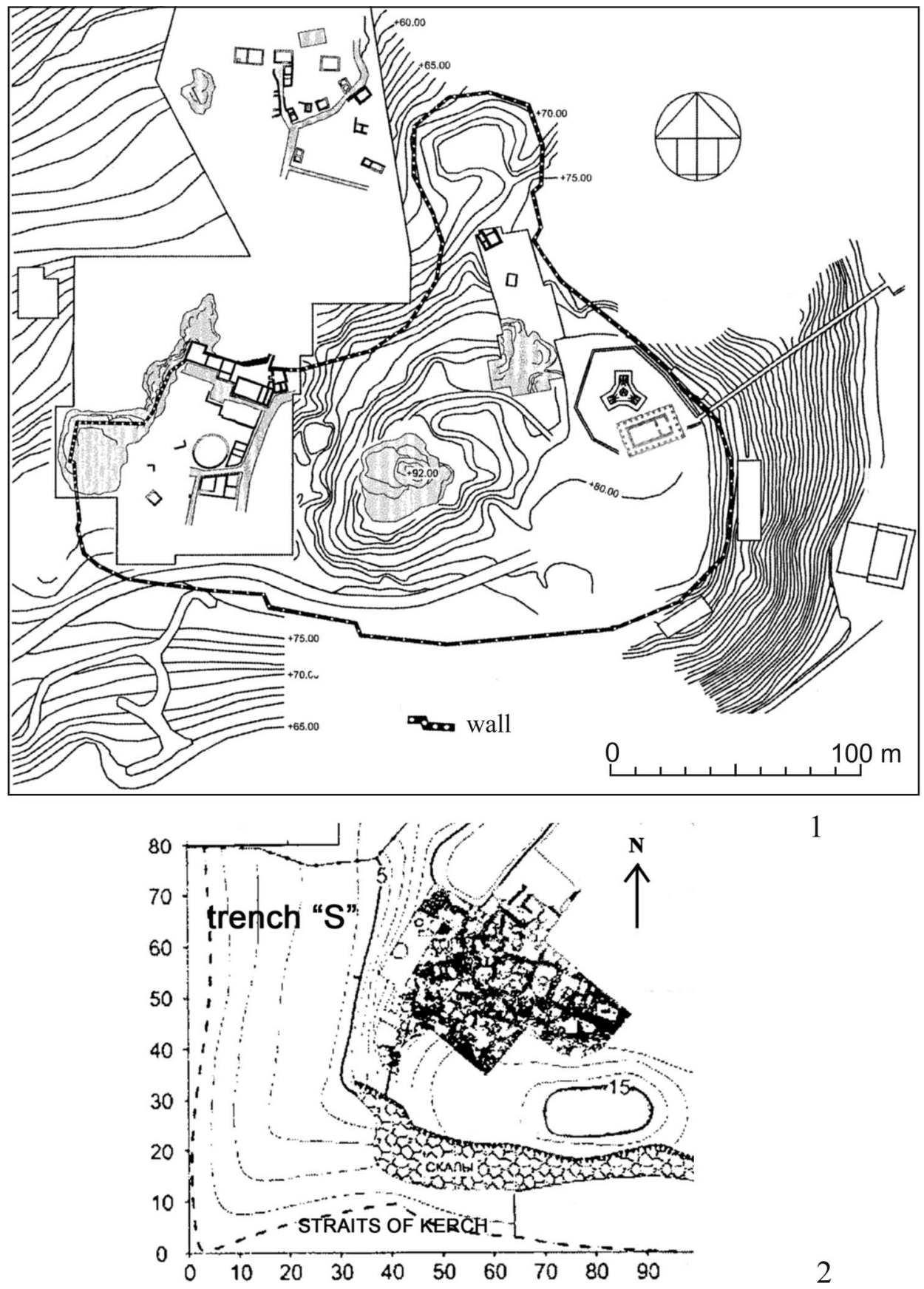

Pl. 2. 1 - Pantikapaion, First Throne of the Mithridates Hill, plan of the acropolis 500485 BC. Reproduced from Tolstikov 2010a, 306; 2 - Myrmekion, plan of the acropolis. Reproduced from Butâgin and Vinogradov 2006, 4-5, pис. 1 


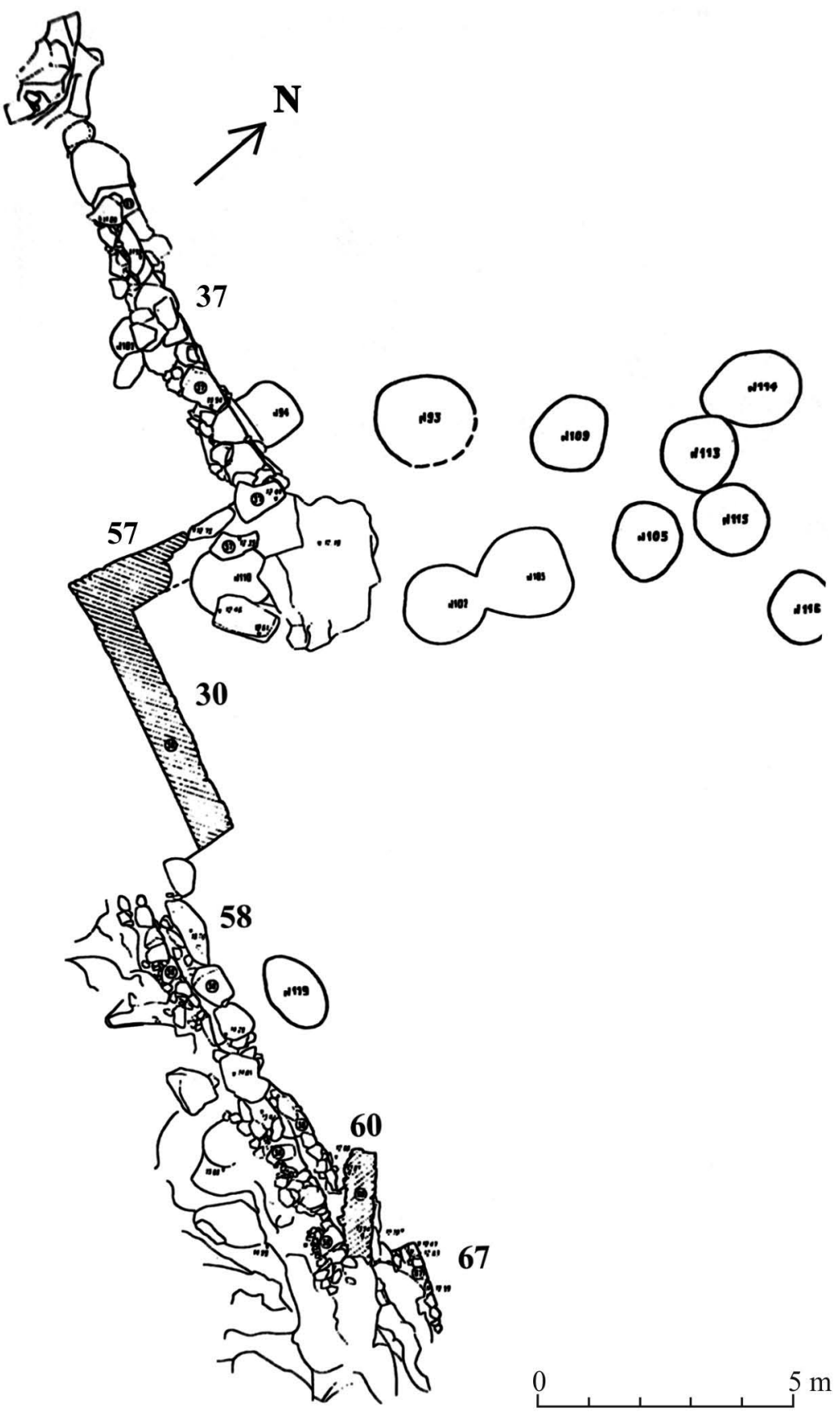

P1. 3. Myrmekion, fortifications of the Akropolis.

Reproduced from Vinogradov 1999, 282, fig. 2 


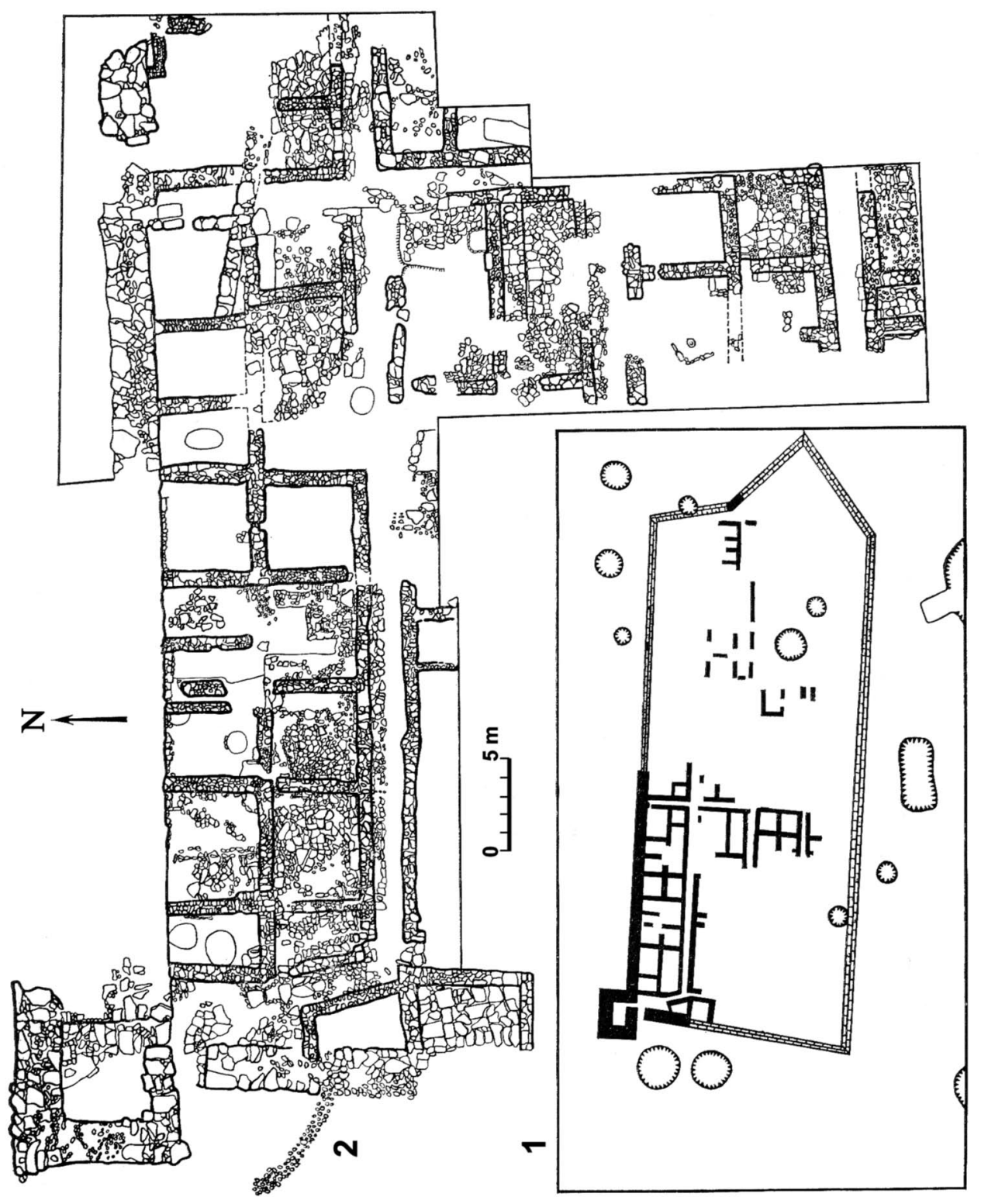

P1. 4. Porthmion. Reproduced form Šurgaâ 1984, 131, таб. 33: 1, 2.

1 - Plan of the city from Classical period; 2 - Plan of northeastern part of the city 


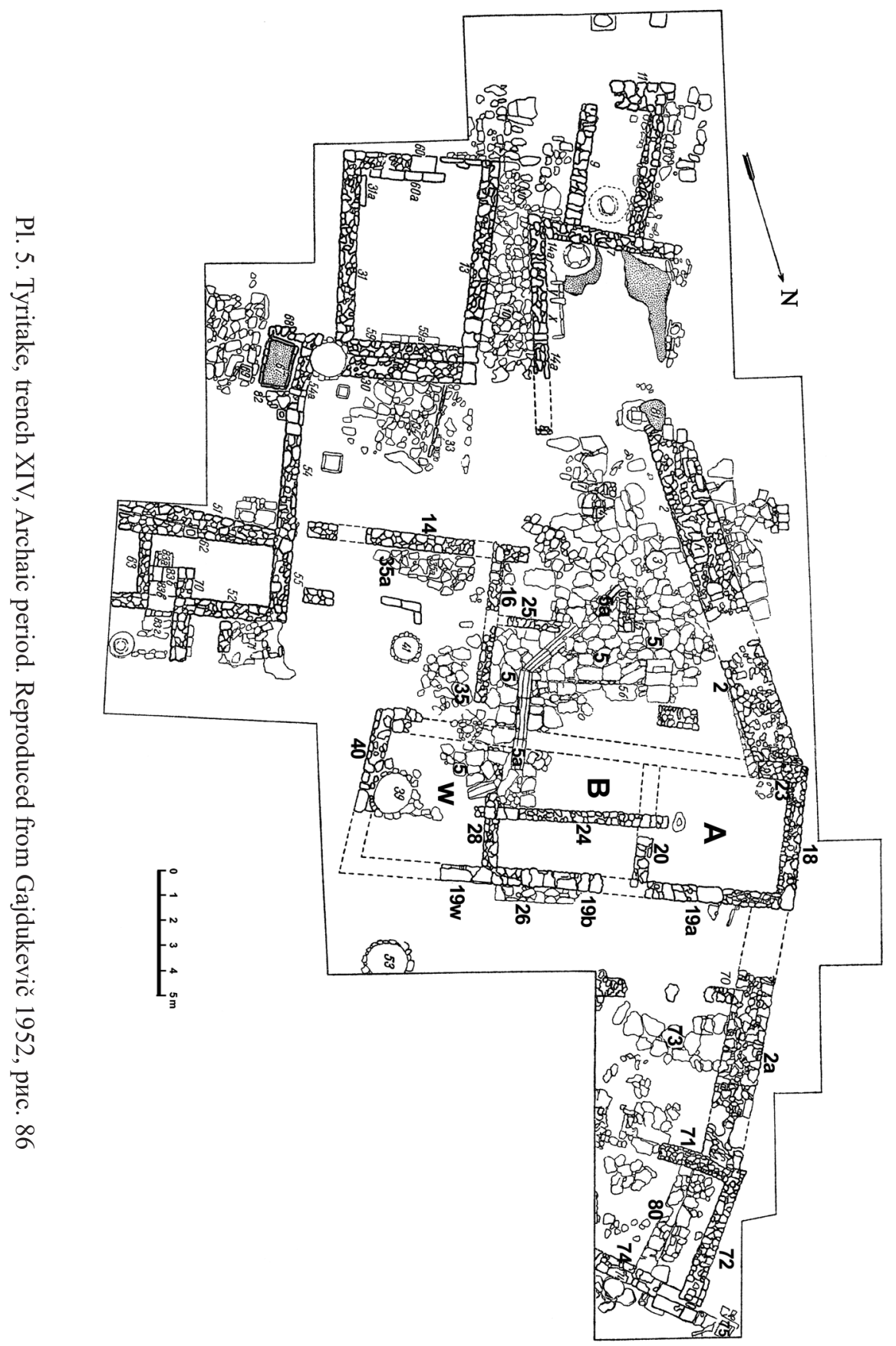




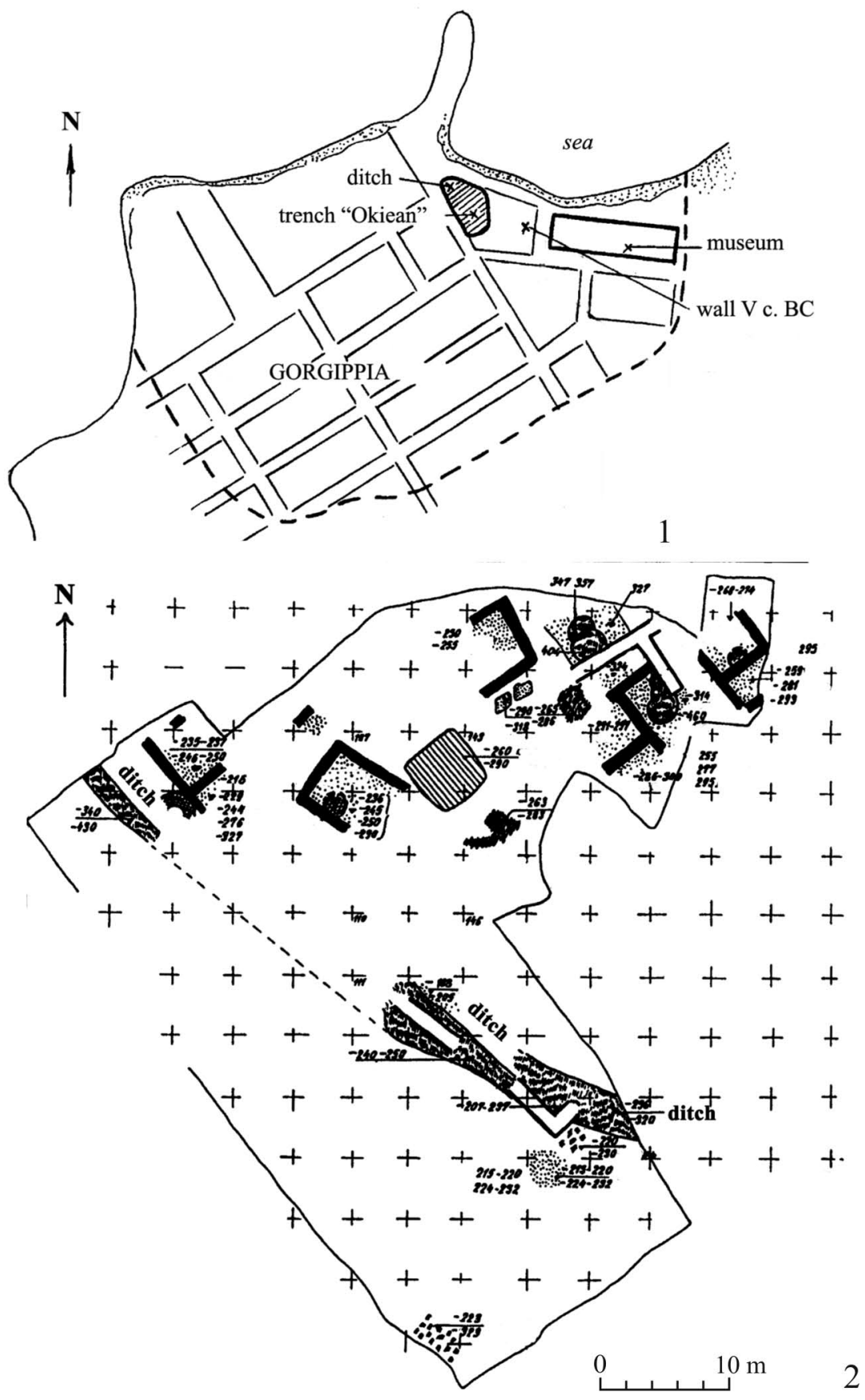

Pl. 6. 1 - Gorgippia, 'Okean' trench. Reproduced from Alekseeva 2003, 28, рис. 1; 2 - Gorgippia, ditch in the 'Okean' trench. Reproduced from Alekseeva 1997, 283, таб. 3 


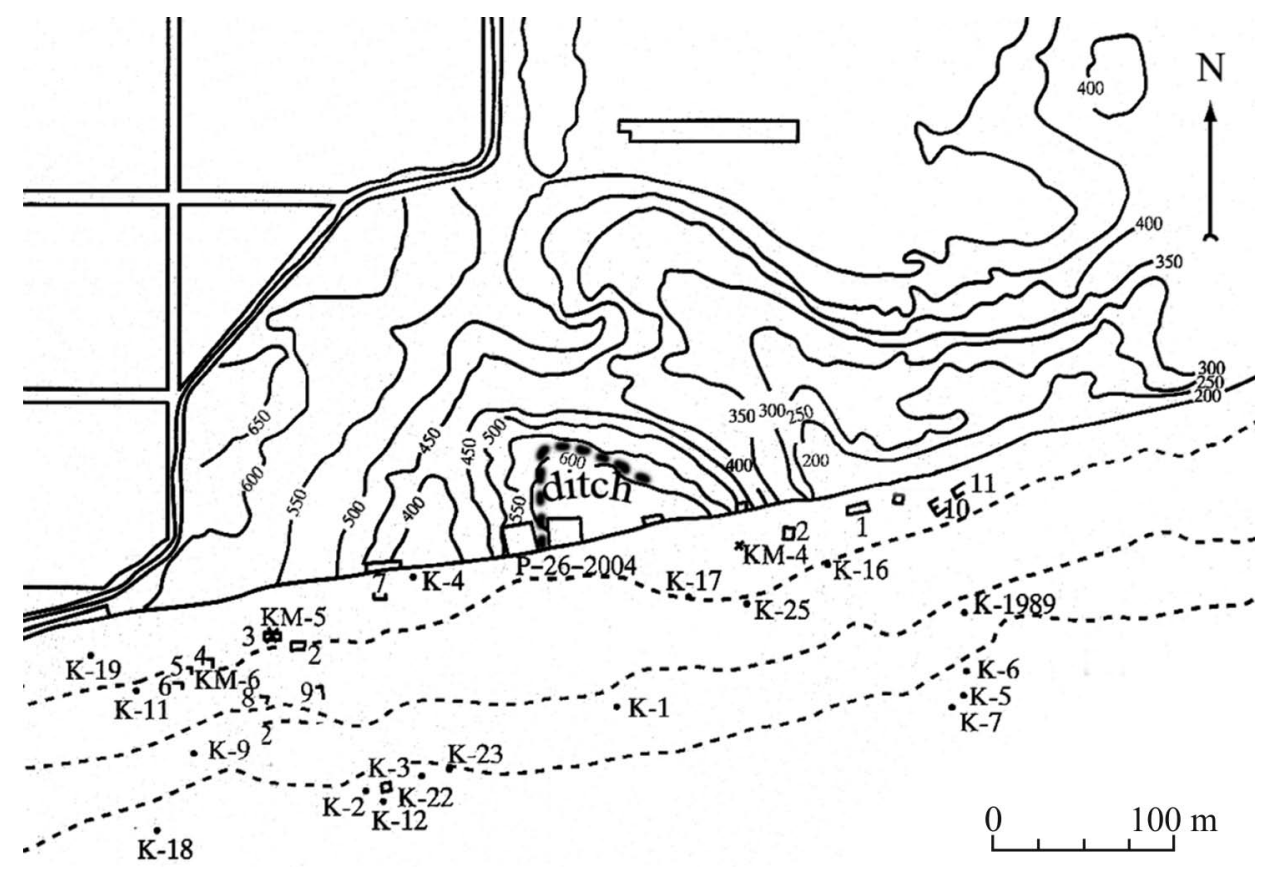

Pl. 7. Plan of Patrasis. Reproduced from Abramov 2010b, 530, рис. 1, and Paromov 1993, рис. 3: 153 


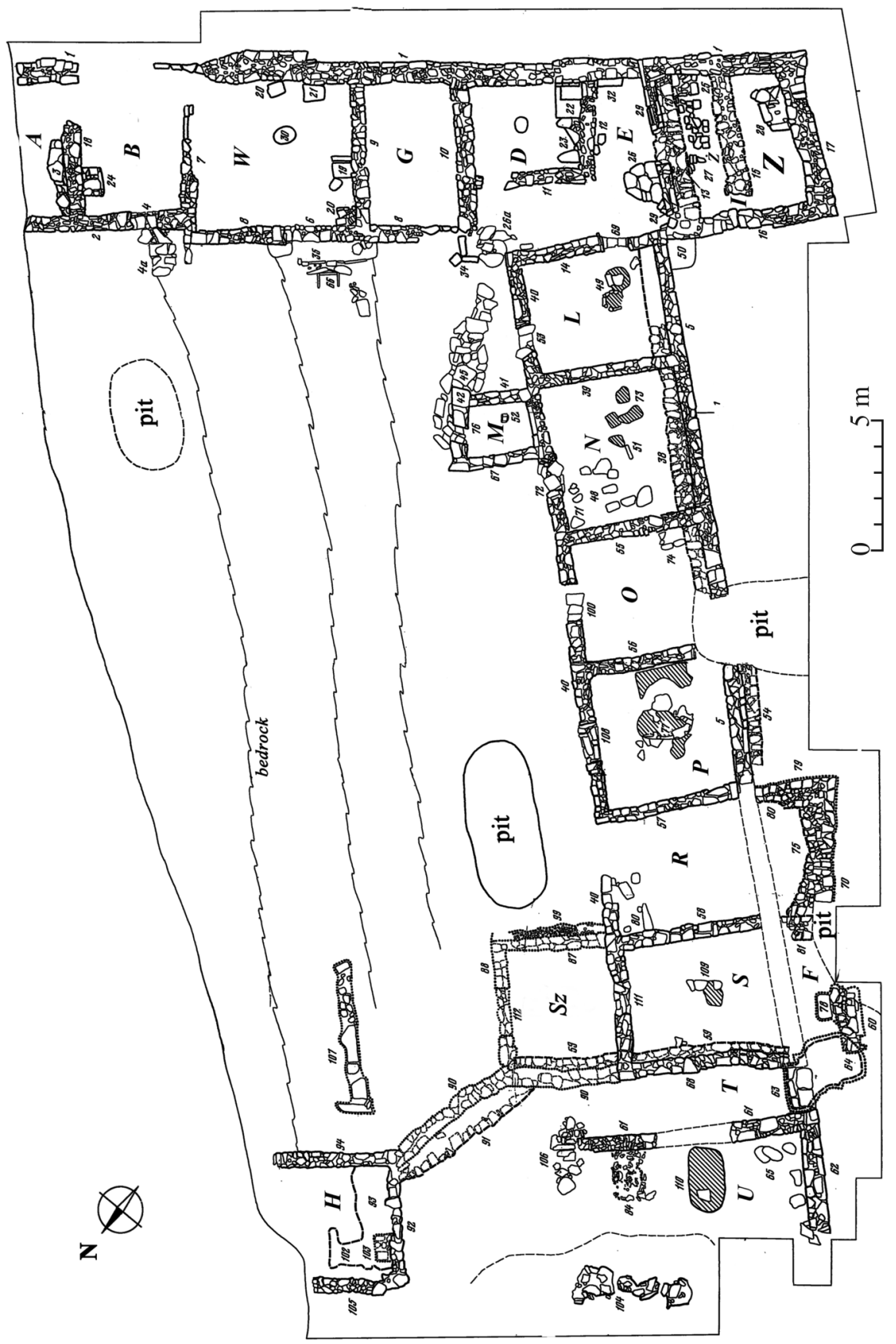

Pl. 8. Plan of Torikos. Reproduced from Onajko 1980, pис. 4 